\title{
(2) Purchase Intension of Second Hand Product that aße Unconsciously Move toward Voluntary Simplicity: A Netnographic Observation from Sweden and Bangladesh
}

\section{Mohammad Ataur Rahman}

Senior Lecturer, Department of Business Administration, Central Women's University, Dhaka-1203, BANGLADESH

*E-mail for correspondence: ctg_ataur@yahoo.com

Received: Aug 07, 2017

Accepted: Jan 2, 2018

Published: Feb 28, 2018

Source of Support: Nil

No Conflict of Interest: Declared

\begin{abstract}
Voluntary simplicity is one of the desired lifestyle that modern consumers wants to live. But, becoming voluntary simplifiers is not an easy task. There are several ways of becoming voluntary simplifiers and one of the common way is buying second hand products. Purchase intension of second hand consumers is maintained by consumers' conscious and unconscious mind. Unconscious mind mainly decide whether a consumer will go for the second hand product or not? In this study, consumers of Sweden and Bangladesh has been focused to check their purchase intension of second hand product that unconsciously move them to become voluntary simplifiers. From the Netnographic observation, it has been found that, Bangladeshi consumers are more voluntary simplifiers than that of Swedish consumers because of their unconscious mind.
\end{abstract}

Keywords: Purchase Intension, Second Hand Product, Netnographic Observation, Sweden, Bangladesh

\section{INTRODUCTION}

Sustainability is the buzzword of today's world. Sustainability issue initially focused on the environment of the world. But, now sustainability discussed on all the business and non-business activities. Even, sustainability is now focusing on the life style of human being. Which product to buy is now somehow depend on the level of sustainability of that product (McDonald et al 2006)? Because, each and every product consume natural resources during its production. So, it is very important to judge which product to consume and which not, which is a very difficult task to do. There are several ways by which people can live sustainably. One of the ways that can help in this regard is Voluntary Simplicity which means live simply. It is a way of life that reject high consumption (Charles 1901). This concept derives from the belief that, high consumption is unethical (Juliet 1998) and not required in a world where people are in great need of basic need consumption.

The Voluntary simplifiers not only reject high consumption but also buy those product which has environmental values (Moisander \& Pesonen 2002). From this perspective, voluntary simplicity concept is somehow similar to sustainable consumption. To distinguish the concept from sustainable consumption, Elgin and Mitchell (1976) proposed five (Material simplicity, Human scale, Self-determination, Ecological awareness and Personal growth) voluntary simplifiers ingredients.

Another thing, Voluntary simplicity does not mean that consumer will reduce his/her needs rather consumer will maintain his/her consumption level by purchasing less material products and purchasing more nonmaterial products (Shama 1996). So, voluntary simplicity is directly connected to consumer behavior which has been studied in psychology as well as marketing (Huneke 2005).

There are plenty of research work on Voluntary simplicity and almost all the research work explains how a consumer can become voluntary simplifiers or what factors help a consumer to become a voluntary simplifiers through his/her consumption. But, no research has explain that consumer can unconsciously diverted to voluntary simplicity by their purchase intention of second hand product. In this research, voluntary simplicity has been discussed from psychological perspective to explore the issue of voluntary simplicity conversion of consumers through purchase intention of second hand product and unconscious mind of consumer.

\section{RESEARCH QUESTION}

Which countries (Sweden and Bangladesh) consumers have more purchasing intention of second hand product that unconsciously moving them to become voluntary simplifiers?

\section{THEORETICAL FRAMEWORK}

\section{What Is Voluntary Simplicity?}

According to Investopedia Dictionary, "Voluntary Simplicity is a lifestyle that minimizes consumption and pursuit of wealth and material goods". The consumer who willingly accept this lifestyle is considered as voluntary simplifiers. 
Voluntary simplifiers can be divided by their inspiration and commitment level. Etzioni (1998) recognizes three types Voluntary Simplifiers. They are: 1) Moderate Simplifiers, 2) Strong Simplifiers and 3) Simple/real Simplifiers. Moderate simplifiers just downshifting there consumption a bit; Strong simplifiers reduce a high level of consumption and Simple/real Simplifiers who passes their whole life in less material consumption

\section{Studying Voluntary Simplifiers}

Voluntary simplicity has been discussed quite a lot in social psychology literature by various researchers. Craig-Lees and Hill (2002) investigate voluntary and non-voluntary simplifiers in Australia and find three issues (ecological, profound, and self-situated) that influence people to become voluntary simplifiers.

Shaw and Newholm (2002) investigate voluntary simplifiers by concentrating on moral consumers and found that morality is the hidden power of becoming voluntary simplifiers.

\section{Voluntary Simplicity and the Ethics of Consumption}

Voluntary simplicity does not only focus on the reduction of high level material consumption but also focus on maintaining need of human being by consuming non-materially.

\section{a) Maintained Levels of Consumption}

Voluntary simplifiers can maintain their current consumption level by choosing innovative green or non-material product (Weizsa cker, Lovins, and Lovins, 1998). So, it is not always necessary to reduce consumption but to change buying pattern.

\section{b) Reduced Levels of Consumption}

It is not possible to consume non material product in every area of life. In such situation, voluntary simplifiers need to reduce his/her current level of consumption. In such situation, Voluntary simplifier can adopt several changes in their way of life to fulfill their needs. In such situation, Voluntary simplifiers can collectively share products (Schor, 1998), that will fulfill their needs and reduce material consumption as well. For example, laundry is shared at family apartments in Sweden.

Another solution can be of repairing (Durning, 1992; Papanek, 1995) the material goods to last more and fulfill their needs. And another alternative solution can be the reuse of products or buying second hand/used product (Myers 1986). Because, second hand products does not need any new material to produce.

\section{Freud's Theory of Mind}

According to Freud (1914), Human mind is categorizes into three level, that are conscious, subconscious and unconscious mind. These three stages of mind create the reality for a human to do or not to do something. Conscious mind is the level of knowledge that is understood as having awareness of something. Subconscious mind is the storage point of recent memories. And Unconscious mind is the storage point of all past memories and experiences that forces human to do or not to do something. According to Freud (1914), Unconscious mind is the level which is considered as decision level of human mind. So, this is the vital level for any individual's activity. Freud (1914) Unconscious mind concept can be used for consumer behavior analysis also.
In this research work, it has been tried to focus on unconscious voluntary simplicity practice of consumers through secondhand product purchase intention and has been tested in the Sweden and Bangladesh. To do this research work, Freud's (1914) theory of unconscious mind has been focused to justify the consumers' behavior analysis. A consumer can automatically become voluntary simplifiers by his/ her unconscious mind and consumption behavior. Consumers often buy second hand product without much thought but to fulfill his/her basic needs or demands. This purchase and consumption actually diverted them toward voluntary simplicity which consumers might not focused of consciously and this issue has been explained in this research work.

\section{Methodology Of THE Study}

This study is based on the observation of users of two Facebook groups of Bangladesh and Sweden. To analyze the consumers' attitude of two Facebook groups, Netnographic observation (Kozinets 2011) has been used. Netnographic Observation has been conducted on two Facebook group from two different countries. Main focus of the observation is to check consumers' intention of buying second hand products which unconsciously lead them towards voluntary simplicity practice. All the observed consumers are from Sweden and Bangladesh. To do this Netnographic observation, focus has been given on the mentioned Facebook groups and check the consumers' attitude and intention towards second hand products by observing their like/comments in the group posts.

\section{Data Sources}

From Sweden "Köpes, säljes, bytes och bortskänkes i Göteborg (https://www.facebook.com/groups/226697710706558/)"

Facebook group has been chosen for Netnographic observation and analysis. This is a public Facebook group which has $12 \mathrm{k}$ members and 493 posts since its starting. The group allow its members to post buy/sell offer for new and second hand products. For the study purpose, observation has been done only on the second hand product posts. Some post has more than 15 replies but few post have $2 / 3$ replies in total. And, more than $90 \%$ post are from Gothenburg area of Sweden. From this group page, 87 posts that has most comments and likes has been chosen, collected and used for the analysis.

From Bangladesh, "ctg second-Hand Bazar (https://www.facebook.com/groups/binimoybazar/)

facebook group has been choosen for netnographic observation and analysis. This is a closed facebook group which has 28k members and 1031 posts since its starting. The group allow its members to post buy/sell offer for new and second hand products. For the study purpose, observation has been done only on the second hand product posts. Some post has more than 20 replies but few post have no replies at all. And, more than $95 \%$ post are from Chittagong area of Bangladesh. From this group page, 202 posts that has most comments and likes has been chosen, collected and used for the analysis.

\section{Data Analysis}

After selecting two data sources from two countries, data has been copied to a simple word document for the analysis purpose and future record. Based on these source, data has been observed and analyzed according to the research content 
of voluntary simplicity based on psychological view point of consciousness and unconsciousness mind.

\section{Data Reliability}

In this two Facebook group, most of the post are from Swedish and Bengali languages. To uniform them for analysis, Google Translator has been used to get the translation of those pos.

\section{Result AND AnAlysis of the Study}

\section{General comparison of Two Facebook Groups}

Netnographic observation of Köpes, säljes, bytes och bortskänkes i Göteborg

- Membership is not controlled: As, it is a public group, membership is open for any person from anywhere of the world. But, from the observation of the group, it is found that, almost all members are from Gothenburg area of Sweden.

- Regularity of posts: After viewing and reading all the post, it has been observed that, post for second hand product posted regularly in this group. Without exception, a new post has been posted daily in the group and the members interact/not interact with the post by giving like or commenting in the post.

- Genuine visualization of products: Most of the images of product attached in the post are genuine. But, few post did not post genuine picture of the product. Genuine visualization helps the members of this group to interact with the post.

- Varieties of product: In this Facebook group, several post has been posted for different products; ranging from furniture, clothes, shoes, consumer electronics, jewelry etc. But, most of the post is related to home or kitchen furniture.

- Less interactivity of Members: In this Facebook group, it has been observed that, most of the posts of this group are not interactive within the members by giving like or writing comments. But, there are some other posts which have more interactivity within the members.

- Unsold products: From the posts observation of this group, it is pretty clear that, $30-40 \%$ of the product remain unsold which is offered for sell. It is a clear sign that, members of this group is not active that much.

- Free of cost Product offering: In this Facebook group, it has been seen that, few products has been posted as free of cost product. It means, the members don't need to pay money if they want to grasp it. And, this types of product has been seen fully sold.

\section{Netnographic observation of ctg second-Hand Bazar}

- Membership is controlled: As, it is a private group, membership is not open for any person from anywhere of the world. But, from the observation of the group, it is found that, almost all members are from Chittagong area of Bangladesh.

- Regularity of posts: After viewing all the post, it has been observed that, post for second hand product posted regularly in this group. Without exception, a new post has been posted daily in the group and the members interact/not interact with the post by giving like or commenting in the post.

- Genuine visualization of products: Most of the images of product attached in the post are genuine. But, few post did not post genuine picture of the product. Genuine visualization helps the members of this group to interact with the post.

- Varieties of product: In this Facebook group, several post has been posted for different products; ranging from furniture, clothes, shoes, consumer electronics, jewelry etc. But, most of the post is related to consumer Electronics.

- More interactivity of Members: In this Facebook group, it has been observed that, most of the posts of this group are interactive within the members by giving like or writing comments. But, there are some other posts which don't have any types of interactivity.

- Unsold products: From the posts observation of this group, it is pretty clear that, $20-30 \%$ of the product remain unsold which is offered for sell. It is a clear sign that, members of this group is not active that much.

- Free of cost product offering: In this Facebook group, no product has been found that is free of cost. All the product posted has a definite charge.

Purchase of Second hand product of two different Countries

Purchase of second hand product in Sweden

\begin{tabular}{|c|c|c|}
\hline $\begin{array}{c}\text { Total Number of Second } \\
\text { hand product post }\end{array}$ & Sold Out & Percentages \\
\hline 402 & 292 & $72.63 \%$ \\
\hline
\end{tabular}

Purchase of second hand product in Bangladesh

\begin{tabular}{|c|c|c|}
\hline $\begin{array}{c}\text { Total Number of Second } \\
\text { hand product post }\end{array}$ & Sold Out & Percentages \\
\hline 892 & 660 & $73.99 \%$ \\
\hline
\end{tabular}

\section{Purchase intention of Second hand product of two different Countries}

Purchase intention of second hand product in Sweden

\begin{tabular}{|c|c|c|}
\hline $\begin{array}{c}\text { Total Number of Second } \\
\text { hand product post }\end{array}$ & $\begin{array}{c}\text { Number of Most } \\
\text { interactive posts }\end{array}$ & Percentages \\
\hline 402 & 87 & $21.64 \%$ \\
\hline
\end{tabular}

Purchase intention of second hand product in Bangladesh

\begin{tabular}{|c|c|c|}
\hline $\begin{array}{c}\text { Total Number of Second } \\
\text { hand product post }\end{array}$ & $\begin{array}{c}\text { Number of Most } \\
\text { interactive posts }\end{array}$ & Percentages \\
\hline 892 & 202 & $22.64 \%$ \\
\hline
\end{tabular}

\section{Voluntary Simplicity Analysis}

From the statistics of group posts of two different countries, it is clear that, Bangladeshi consumers have more positive interest on second hand product than that of Swedish Consumers. According to Freud (1914), Unconscious mind forces people to decide on what to do or what not to do? Looking at this point of view, it can be said that conscious mind of Swedish consumers is more powerful than their unconscious mind that hinders themselves to go for second hand product or even reacting less on second hand product offering.

For example, a conversation for a second hand washing machine can be a good example of this:

Petra Blendulf: Highly interested. Would like some more info. Please send pm

Victor Jansson: Hey written PM to you 
Petra Blendulf: how old is it?

Victor Jansson: 3 years but functioning without error

Petra Blendulf: I've changed my mind

Although, Petra was so much interested initially to buy the product. But, all of a sudden Petra changed his mind to buy the product because his conscious mind forces him not to buy the 3 year old washing machine.

On the other hand, Bangladeshi consumers' unconscious mind is more powerful than their conscious mind and due to that they react or buy more second hand product. So, this unconscious mind helps the Bangladeshi consumers to unconsciously move toward voluntary simplicity.

For example, a conversation for a second hand mobile phone can be a good example of this:

\section{Mostafa Al Amin: Highly Interested. Send pm to you Abdullah: Thanks, but there is little scratch on the back of the mobile. Is it okay for you? \\ Mostafa Al Amin: Scratch is not a problem. Is the mobile functioning correctly? \\ Abdullah: Yes \\ Mostafa Al Amin: Done. I will go for it.}

Mostafa $\mathrm{Al}$ amin was highly interested to buy the product although he did not know about the scratch problem. Even after knowing the problem, he did not change his mind. Here, conscious mind is not working for Mostafa. Rather, unconscious mind forces him to decide to buy the mobile phone.

From the above analysis from different perspectives, it is clear that, Bangladeshi consumers have more intention to buy second hand product and their unconscious mind turns them to become voluntary simplifiers than that of Swedish consumers.

\section{CONCLUSION AND Future RESEARCH}

This study has examined the consumers purchase intention of second hand product in Sweden and Bangladesh which has been used as a barometer of becoming a voluntary simplicity consumers from psychological perspective. The study reveals that, consumers in Bangladesh are comparatively more voluntary simplifiers than that of Swedish consumers as they have more intention to purchase second hand products. This study is only based on the Netnographic observation and this is a qualitative evidence of voluntary simplicity issue of two different countries based on the consumers' intention of purchasing second hand product. And the study explores results based on two Facebook group of two countries. And this voluntary simplicity issue can be explored in broader perspective through future research.

\section{REFERENCES}

Craig-Lees, M., \& Hill, C., (2002). Understanding voluntary simplifiers. Psychology \& Marketing, 19, 187-210

Durning, A. (1992). How much is enough? The consumer society and the future of the earth. London: Earthscan.
Elgin, D., \& Mitchell, A. (1976). Voluntary simplicity. Business Intelligence Program, SRI International. Reprinted in Elgin, D., \& Mitchell, A. (1977). Voluntary simplicity (3). The CoEvolution Quarterly, 3 (Summer), 4-19.

Etzioni, A. (1998). Voluntary simplicity: Characterization, select psychological implications, and societal consequences. Journal of Economic Psychology, 19, 619-643.

Kozinets, V. R. (2011). Netnografi: Etnografiska undersökningar på nätet. 1:a upplagan. Lund

Maslow,A. (1943).A preface to human motivation. Psychosomatic Medicine, 5, 85-92.

McDonald et al, Toward Sustainable Consumption: Researching Voluntary Simplifiers, Psychology \& Marketing, Vol. 23(6): 515-534 (June 2006), Wiley Online Library

Moisander, J., \& Pesonen, S. (2002). Narratives of sustainable ways of living: Constructing the self and the other as a green consumer. Management Decision, 40, 329-342.

Myers, K. (1986). Under-stains: And the sense and seduction of advertising. London: Comedia.

Papanek, V. (1995). The green imperative. London: Thames and Hudson.

Schor, J. (1998). The overspent American. New York: Basic Books.

Shama, A. (1996). A comment on "The meaning and morality of voluntary simplicity: History and hypothesis on deliberately denied materialism." In R. W. Belk, N. Dholakia, \& A. Venkatesh (Eds.), Consumption and marketing: Macrodimensions (pp. 216-224). Cincinnati, OH: SouthWestern College Publishing.

Shama, A., \& Wisenblit, J. (1984). Values of voluntary simplicity: Lifestyle and motivation. Psychological Reports, 55, 231-240.

Shaw, D., \& Newholm, T, (2002). Voluntary simplicity and the ethics of consumption. Psychology \& Marketing, 19, 167-185

Shaw, D., \& Newholm, T, (2002). Voluntary simplicity and the ethics of consumption. Psychology \& Marketing, 19, 167-185.

Sigmund Freud, "psychopathology of Everyday life" NEW YORK: THE MACMILLAN COMPANY, 1914

Stihler, Ariane. "Juliet B. Schor: The Overspent American. Upscaling, Downshifting, and the New Consumer. New York: Basic Books, 1998." Journal of Consumer Policy 23.3 (1998): 341-47. Web.

Stundentlitteratur. Mary E.Huneke, "The Face of the Un-consumer: An Empirical Examination of the Practice of Voluntary Simplicity in the United States." Psychology \& Marketing, Vol. 22(7): 527-550 (July 2005), Wiley Online Library.

WAGNER, Charles, Mary Louise. HENDEE, and Grace Elizabeth. KING. The Simple Life ... Translated from the French by Mary L. Hendee. With an Introduction and Biographical Sketch by G. King. Pp. Xxxix. 193. McClure, Phillips \& Co.: London, 1901. Print.

Weizsa"cker, E. V., Lovins, A., \& Lovins, H. (1998). Factor four: Doubling wealt-halving resource use. London: Earthscan.

\section{SOCIAL SCIENCE RESEARCH NETWORK 2171 Monroe Avenue, Suite 203, Rochester, NY 14618, USA http://www.ssrn.com/en/}

AJTP Link: http://www.ssrn.com/link/American-Journal-Trade-Policy.html 